\title{
Isyarat-isyarat Manajemen Mutu Pendidikan Dalam Al-Qur'an dan Al-Hadits
}

\author{
Tio Ari Laksono \\ Pascasarjana IAIN Tulungagung, Indonesia \\ E-Mail:dilandalarva3@gmail.com
}

DOI: https://doi.org/10.21154/ sajiem.v2i1.38

\begin{abstract}
Quality is conformance to requirement, that is, a product is said to be of quality when it has reached the agreed standard target. This research examines the quality cues found in the sources of Islamic law, namely the Al-Quran and al-hadith. To strengthen the quality management of education according to the perceptions of legal sources and Muslim scholars. The data collection process was carried out through library research. Something is said to have quality when something has a good meaning and vice versa. In the context of education, if someone says a school is a quality, it can be interpreted that the graduates are quality, the teachers are qualified, the building is proper, and so on. To mark something that has quality or not, someone gives symbols with certain names, for example, superior schools, model schools, pilot schools, and so on. Quality is the realization of Ihsan's teachings, which is to do good to all parties because Allah has done well to humans with His various favors, and is prohibited from doing damage in any form.
\end{abstract}

\section{Keywords: Education Quality Management, Al-Quran, Al-Hadith}

\begin{abstract}
Abstrak
Mutu merupakan conformance to requirement, yaitu produk dikatakan berkualitas ketika sudah mencapai target standar yang di sepakati. Penelitian ini mengkaji isyarat mutu yang terdapat pada sumber hukum umat islam yaitu al-quran dan al-hadits. Dengan tujuan memperkuat manajemen mutu pendidikan menurut persepsi sumber hukum dan para ahli muslim. Proses pengumpulan data dilakukan melalui studi pustaka (Library Research). Sesuatu itu dikatakan bermutu ketika sesuatu itu mengandung makna yang baik dan sebaliknya. Dalam konteks pendidikan, apabila seseorang mengatakan sekolah itu bermutu, maka bisa dimaknai bahwa lulusannya berkualitas, gurunya mumpuni, gedungnya layak, dan sebagainya. Untuk menandai sesuatu itu bermutu atau tidak seseorang memberikan simbol-simbol dengan sebutan-sebutan tertentu, misalnya sekolah unggulan, sekolah teladan, sekolah percontohan dan lain sebagainya. Mutu merupakan realisasi dari ajaran ihsan, yakni berbuat baik kepada semua pihak disebabkan karena Allah telah berbuat baik kepada manusia dengan aneka nikmat-Nya, dan dilarang berbuat kerusakan dalam bentuk apapun.
\end{abstract}

Kata Kunci: Manajemen Mutu Pendidikan, Al-Quran, Al-Hadits 


\section{Pendahuluan}

Manajemen sangat diperlukan untuk mencapai tujuan pendidikan. Manajemen adalah kemampuan untuk mengatur dan melakukan kegiatan dengan baik. Proses pendidikan jika dijalankan tanpa dibarengi dengan fungsi-fungsi manajemen berupa: perencanaan pengorganisasian, penggerak serta pengawasan maka tidak akan maksimal tercapainya tujuan pendidikan, karena sudah dapat dipastikan pelaksanaan pendidikan akan semrawut berjalan sendiri-sendiri tanpa adanya manajemen atau kerja sama yang telah disepakati dalam peningkatan mutu lembaga pendidikan. Istilah total quality manajment merupakan penafsiran dari seluruh tugas-tugas yang telah dimanajerial dengan baik maka akan menghasilkan mutu atau kualitas yang baik dan maksimal.

Mutu merupakan sebuah ukuran berkualitas atau buruk suatu benda dengan kadar taraf derajat kecerdasan, kepandaian dan lainnya. Dalam Bahasa Inggris, mutu disebut atau diistilahkan dengan "quality". Tidak bisa di pungkiri bahwa mutu selalu melekat pada konsep input, proses, dan output. Ketiga konsep tersebut tidak dapat dipisahkan dari manajeme mutu dan semuanya terkain satu dengan yang lain demi mencapai tujuan yang di impikan. Manajemen mutu dalam konteks lembaga pendidikan merupakan metodologi mengenai perbaikan yang dilaksanakan secara terarah dan berkesinambungan sehingga mendapatkan alat yang praktis untuk menunjang lembaga pendidikan dalam memenuhi harapan, keinginan, dan kebutuhan, pelanggan, saat ini maupun masa yang akan datang.

Perbaikan kualitas atau mutu membuthkan beberapa pendekatan sistem secara menyeluruh. Pendekatan tersebut juga dapat di terapkan pada perbaikan mutu lembaga pendidikan islam. Lembaga pendidikan yang bernafaskan islam seperti pesantre, madrasah dan lain sebagainya tidak boleh tertinggal dalam mengupayakan quality improvement namung dengan tidak meninggalkan pegangan utama umat islam yaitu al-quran dan al-hadits atau mungkin tokoh-tokoh pemikir islam yang telah mencetuskan teori-teori mengenai perbaikan mutu.

\section{Metode Penelitian}

Penulisan penelitian ini menggunakan jenis penelitian Library Research yang mana proses pengumpulan data dilakukan dan diperoleh melalui kajian Kepustakaan. Studi pustaka atau kepustakaan dapat diartikan sebagai serangkaian kegiatan yang berkenaan dengan metode pengumpulan data pustaka, membaca dan mencatat serta mengolah bahan penelitian. Dalam penelitian studi pustaka setidaknya ada empat ciri utama yang penulis perlu perhatikan diantaranya: Pertama, bahwa penulis atau peneliti berhadapan langsung dengan teks (nash) atau data angka, bukan dengan pengetahuan langsung dari lapangan. Kedua, data pustaka bersifat "siap pakai" artinya peniliti tidak terjung langsung kelapangan karena peneliti berhadapan langsung dengan sumber data yang ada di perpustakaan. Ketiga, bahwa data pustaka umumnya adalah sumber sekunder, dalam arti bahwa peneliti memperoleh bahan atau data dari tangan kedua dan bukan data orisinil dari data pertama di lapangan. Keempat, bahwa kondisi data pustaka tidak dibatasi oleh ruang dan waktu. Berdasarkan dengan hal tersebut diatas, eksplorasi terhadap sejumlah data baik data primer maupun sekunder peneliti membaca atau menelaah buku-buku mengenai manajemen mutu, jurnal, artikel, maupun laporan hasil penelitian terdahulu yang relevan dengan penelitian peneliti serta berkaitan dengan manajemen mutu pendidikan.

${ }^{\prime}$ M. H. Masyitoh, “Manajemen Mutu Pendidikan Perspektif QS. Ar-Ra'du Ayat 11 Dan Impelemtasinya Dalam Pengelolaan Madrasah” dalam JUMPA Jurnal Manajemen Pendidikan, Vol. 1, No. 1, Februari - Oktober 2020, 3. 


\section{Hasil dan Pembahasan}

Konsep Islam mengajarkan bahwa dalam memberikan layanan dari usaha yang dijalankan baik itu berupa barang atau jasa harus memberikan kualitas/mutu dan menjamin kepuasan konsumen. Bagi seorang muslim menjalankan usaha merupakan ibadah, sehingga usaha itu harus dimulai dengan niat yang suci (lillahi ta'ala), kemudian diikuti dengan cara yang benar, tujuan yang benar, serta pemanfaatan hasil usaha secara benar pula. Memberikan kualitas yang baik sudah di jelaskan dalam al-quran surat al-baqarah ayat 267:

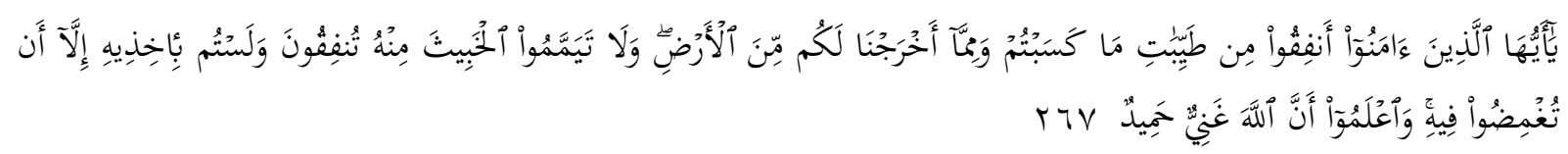

Artinya: Hai orang-orang yang beriman, nafkahkanlah (di jalan allah) sebagian dari hasil usahamu yang baik-baik dan sebagian dari apa yang Kami keluarkan dari bumi untuk kamu. Dan janganlah kamu memilih yang buruk-buruk lalu kamu menafkahkan daripadanya, padahal kamu sendiri tidak mau mengambilnya melainkan dengan memincingkan mata terhadapnya. Dan ketahuilah, bahwa Allah Maha Kaya lagi Maha Terpuji.(QS. Al-Baqarah:267) ${ }^{2}$.

Firman Alloh pada akhir ayat ini, yang artinya sebagai berikut "Ketahuilah, bahwasanya Allah Mahakaya dan Maha Terpuji." Kalimat ini merupakan peringatan, utamanya pada manusia-manusia yang tidak memikirkan kualitas apa yang di berikan kepada orang lain (memberikan sesuatu yang tidak layak), sesungguhnya Allah tidak membutuhkan sedekah semacam itu. Allah tidak akan menerima perbuatan tersebut sebagai amal. Bila seseorang benar-benar ingin berbuat kebaikan dan mencari keridaan Allah, mengapa dia memberikan barang yang buruk, yang dia sendiri tidak menyukainya? Allah Mahakaya. Maha Terpuji dan pujian yang layak bagi Allah ialah bahwa kita rela menafkahkan sesuatu yang baik dari harta milik kita, yang dikaruniakan Allah kepada kita. Dari penjelasan diats dapat di ambil kesimpulan bahwa dalam konsep umat islam pun kualitas atau mutu sangat diutamakan.

Terdapat banyak pengertian tentang mutu atau kualitas. Dalam Kamus Lengkap Bahasa Indonesia, mutu ialah suatu nilai atau keadaan. Sementara pengertian lain tentang mutu dikemukakan oleh para ahli dilihat dari sudut pandang yang berbeda, sebagai berikut: ${ }^{3}$

1. Crosby mendefiniskan mutu kualitas adalah conformance to requirement, yaitu produk dikatakan berkualitas ketika sudah mencapai target standar yang di sepakati. Standar mutu atau kualitas meliputi bahan, proses, dan hasil.

2. Elliot menyebutkan mutu adalah sesuatu yang disesuaikan dengan kebutuhan orang dan tergantung pada tujuan.

3. Menurut American Society For Quality Control, Mutu adalah totalitas bentuk dan karakteristik barang atau jasa yang menunjukan kemampuannya untuk kebutuhankebutuhan yang tampak jelas maupun tersembunyi.

4. Kaoru Ishikawa mengatakan bahwa mutu merupakan rasa puas dari konsumen. Dengan demikian, dalam setiap kegiatan organisasi pasti mempunyai pelanggan. Tolak ukur kepuasan dari anggota akan menimbulkan kepuasan pelanggan organisasi.

5. Menurut Garvin sebagaimana dikutip oleh M.N. Nasution, kualitas adalah suatu keadaan yang berubah-ubah yang disesuaikan dengan produk, manusia atau SDM, proses dan tugas, serta lingkungan yang memenuhi atau melebihi harapan pelanggan atau konsumen. Setiap konsumen mempunyai tujuan dan harapan masing-masing dari suatu produk, maka produk selalu berubah-ubah mengikuti keinginan konsumen. Dari setiap perubahan

\footnotetext{
${ }^{2}$ Kojin Mashudi, Telaah Tafsir Al-Muyassar, (Malang: Intelejensi Manusia, 2018), 231.

${ }^{3}$ Hasan Baharun dan Zamroni, Manajemen Mutu Pendidikan Ikhtiar dalam Meningkatkan Mutu Pendidikan Madrasah melalui Pendekatan Balanced Scorecard, (Tulungagung: Akademia Pustaka, 2017), 63.
} 
diharapkan selalu ada peningkatan kualitas sehingga tingkat kepercayaan pelanggan akan terjaga.

6. Mutu dalam konsep Deming ialah dapat menyesuaikan dengan keinginan konsumen.

7. Aan Komariyah menyatakan bahwa mutu merupakan satndart yang telah disepakati untuk menilai produk barang atau jasa tertentu dengan mempertimbangkan berbagai aspek. $^{4}$

8. Menurut Feigenbaum, sebagaimana dikutip Abdul Hadis dan Nurhayati, mutu merupakan rasa terpenuhinya keinginan konsumen (full customer satisfaction). Suatu barang/produk dikatakan berkualitas apabila dapat memberikan rasa puas dari para pelanggan. ${ }^{5}$

Mutu (quality) akhir-akhir ini mendapat perhatian khusus sehingga banyak diperbincangkan hampir setiap sektor kehidupan dari kalangan pemerintahan, pembisnis, lembaga pendidikan dan sektor lainnya. Secara terminologi, pengertian mutu sebenarnya menimbulkan multi tafsir diantara kalangan ahli. Hal ini dikarenakan tidak adanya patokan yang standar mengenai mutu sendiri. Sehingga sangat susah untuk menyeragamkan jawaban dan pendapat mengenai mutu karena setiap orang mempunyai standar sesuai kebutuhannya. ${ }^{6}$ Alasan definisi relatif, pada kenyataannya terdapat perbedaan antara kepentingan subyek penghasil barang atau jasa dengan kepentingan pemakai barang atau jasa. Namun pada kenyataannya ketika produksi di sesuaikan dengan kepentikan konsumen, konsumen sendiri lebih menilai mutu berdasar persepsi masing-masing.

Pengertian mutu dalam konteks lembaga pendidikan mencakup input, proses, dan output pendidikan. ${ }^{7}$ Input merupakan segala sesuatu yang harus ada dalam pendidikan karena input sangat mempengaruhi berlangsungnya sebuah proses, misalnya: kepsek, siswa, sarpras, dan lainnya. Proses merupakan sebuah usaha demi tercapainya output yang diinginkan, misalnya: monitoring, evaluasi, dan lainnya. Sedangkan output adalah hasil kerja dari suatu lembaga pendidikan dalam meningkatkan kualitas mutu pendidikannya, misalnya: prestasi yang dihasilkan siswa, dan lainnya.

Ukuran mutu secara keseluruhan sangat susah untuk di terapkan pada dunia pendidikan dikarenakan penilaian dari setiap individu berbeda dan manajemen jasa yang heterogen. Orang akan memandangnya dari berbagai arah dan semua arah atau aspek memiliki ukuranukuran mutu tertentu. Oleh karenanya ukuran standar mutu harus diterapkan secara relatif, yaitu ditetapkan berdasarkan kebutuhan konsumen. Dalam hal ini tidak hanya produsen yang menentukan standr mutu, melainkan konsumen harus ikut serta menentukan standar mutu sesuai dengan kebutuhan. Dengan demikian, standart mutu yang dapat berubah-ubah dan relatif dapat dikatakan sebagai mutu terbaik karena siap menyesuaikan dengan kebutuhan konsumen. Mutu lembaga pendidikan dapat dikatakan baik jika lembaga pendidikan bisa memberikan jasa yang sesuai dengan kebutuhan konsumen. ${ }^{8}$

Mutu pendidikan di Indonesia dirasa semakin merosot. Mutu pendidikan Indonesia kalah dengan Malaysia. Dahulu Indonesia jauh berada di atas Malaysia. Faktor penyebab rendahnya mutu berasal dari berbagai faktor baik internal maupun eksternal. Upaya perbaikan mutu terus dilakukan, akan tetapi pada kenyataannya kurang atau bahkan tidak berhasil. Hal ini disebabkan oleh pertama, penggunaan strategi pendidikan yang bersifat input oriented. Kedua, pengelolaan pendidikan yang masih bersifat macro oriented. ${ }^{9}$

\footnotetext{
${ }^{4}$ Aan Komariyah dan Cepi Triatna, Visonary Leadership Menuju Sekolah Efektif, (Jakarta: P. T. Bumi Aksara, 2008), 9.

${ }^{5}$ Abdul Hadis dan Nurhayati, Manajemen Mutu Pendidikan, (Bandung: Alfabeta, 2010), 86.

${ }^{6}$ Muhammad Fathurrohman,Manajemen Mutu Pendidikan Islam Dalam Perspektif Alqur'an Dan Hadits, AL-WIJDÁN Journal of Islamic Education Studies, Volume III, Nomor 2, November 2018, 192.

${ }^{7}$ Hasan Baharun dkk, Manajemen Mutu..., 66.

${ }^{8}$ Ibid., 194.

${ }^{9}$ M. Ali Hasan dan Mukti Ali, Kapita Selekta Pendidikan Islam, (Jakarta: Pedoman Ilmu Jaya, 2003),
} 207. 
Lembaga pendidikan bisa menghasilkan lulusan (output) yang bermutu apabila penyelenggaraan pendidikan mutunya juga terjamin. Mutu pendidikan akan terjamin ketika kepala sekolah melaksanakan fungsi kepemimpinannya dengan baik dan dibarengi komponen pendidikan yang berkualitas juga atau dalam bahasa lainnya adanya terjadi sinergitas yang berorientasi pada mutu pendidikan antara pemimpin dengan seluruh civitas akademika di lembaga pendidikan atau sekolah. ${ }^{10}$

Secara umum kriteria yang telah disepakati bahwa sesuatu itu dikatakan bermutu/berkualitas, pasti ketika produk atau jasa itu bernilai baik atau dapat memberikan kepuasan kepada pelanggan. Sebaliknya sesuatu itu dikatakan tidak bermutu, bila sesuatu itu mempunyai nilai yang kurang baik. Dalam konteks pendidikan, apabila seseorang mengatakan sekolah itu bermutu, maka dapat dipastikan bahwa output lulusan berkualitas, gurunya mumpuni, gedungnya layak, dan sebagainya. Untuk menandai sesuatu itu bermutu atau tidak seseorang memberikan simbol-simbol dengan sebutan-sebutan tertentu, misalnya sekolah unggulan, sekolah teladan, sekolah percontohan dan lain sebagainya.

\section{Isyarat Mutu Dalam Al-Quran}

Mutu merupakan realisasi dari ajaran ihsan, yakni berbuat baik kepada semua pihak disebabkan karena Allah telah berbuat baik kepada manusia dengan aneka nikmat-Nya, dan dilarang berbuat kerusakan dalam bentuk apapun. Ihsan berasal dari kata husn, yang artinya menunjuk pada kualitas sesuatu yang baik dan indah. Dictionary menyatakan bahwa kata husn, dalam pengertian yang umum, bermakna setiap kualitas yang positif (kebajikan, kejujuran, indah, ramah, menyenangkan, selaras, dll). ${ }^{\text {II }}$ Dalam terminologi ilmu tasawuf, ihsan berarti seseorang menyembah Allah seolah-olah ia melihatNya, dan jika ia tidak mampu membayangkan malihatNya, maka orang tersebut mambayangkan bahwa sesungguhnya Allah melihat perbuatannya. Dengan kata lain ikhlas dalam beribadah atau ikhlas dalam melaksanakan islam dan iman. Jadi ihsan menunjukkan satu kondisi kejiwaan manusia, berupa penghayatan bahwa dirinya senantiasa diawasi oleh Allah. Perasaan ini akan melahirkan sikap hati-hati waspada dan terkendalinya suasana jiwa. Pada prinsipnya ihsan adalah kualitas beragamanya seorang muslim.

Kata husn sering disamakan dengan kata khayr. Namun perlu diketahui bahwa husn adalah kebaikan yang tidak dapat dilepaskan dari keindahan dan sifat sifat yang memikat, sementara itu khayr merupakan suatu kebaikan yang memberikan kegunaan konkrit, sekalipun sesuatu tersebut tidak indah dan tidak bersifat memikat. ${ }^{12}$ Jadi bisa dikatakan bahwa husn lebih dari sekedar khair (baik). dalam al-Qur'an surah al-Qashash/28: 77:

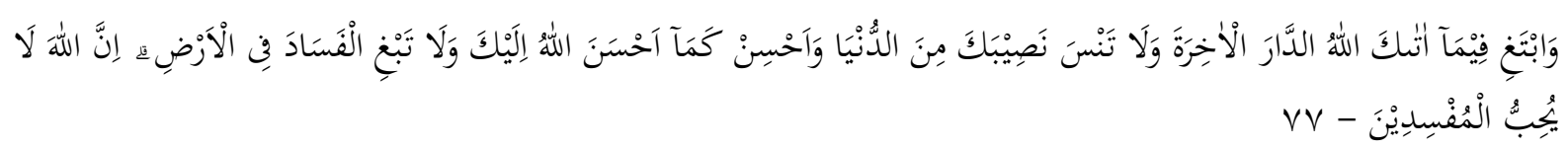

Artinya: Dan carilah pada apa yang telah dianugerahkan Allah kepadamu (kebahagiaan) negeri akhirat, dan janganlah kamu melupakan bahagianmu dari (kenikmatan) duniawi dan berbuat baiklah (kepada orang lain) sebagaimana Allah telah berbuat baik, kepadamu, dan janganlah kamu berbuat kerusakan di (muka) bumi.

${ }^{10}$ Aminatul Zahroh dan Binti Maunah, TOTAL QUALITY MANAGEMENT (TQM): Sebuah Langkah dalam Mengedepankan Kualitas Output melalui Sistem Kontrol Mutu (Quality Control) Sekolah, Jurnal Realita, Vol. 13 No. 2 Juli 2015, 228.

"1 Sachiko Murata dan William C.Chittick, Trilogi Islam: Islam, Iman, dan Ihsan, terjemah :Ghufron A, (Jakarta: Raja Grafindo Persada, 1997), 294.

${ }^{12}$ Ibid., 294 . 
Sesungguhnya Allah tidak menyukai orang-orang yang berbuat kerusakan (QS. AlQasas:77). ${ }^{13}$

Carilah kenikmatan di akhirat yaitu surga yang penuh dengan kenikmatan yang disediakan Allah untuk kamu dengan beriman dan beramal saleh sebanyak-banyaknya, tetapi janganlah kamu mengabaikan kesempatan untuk mendapatkan kenikmatan dunia yang halal dan baik. Dan berbuat baiklah terhadap sesama hamba Allah dengan melakukan tolong menolong dan berbagi kegembiraan! Jauhilah kamu dari perbuatan zalim, permusuhan, serta perbuatanperbuatan yang dapat merusak dan merugikan pada sesama, karena perbuatanperbuatan jelek seperti itu dapat mendatangkan murka Allah. Dia tidak menyukai orang-orang yang berbuat kerusakan di muka bumi. ${ }^{14}$

Maka dari itu, dalam konteks manajemen peningkatan mutu pendidikan Islam, sesuatu dikatakan bermutu jika memberikan kebaikan, baik kepada dirinya sendiri (lembaga pendidikan itu sendiri), kepada orang lain (stakeholder dan pelanggan). Maksud dari memberikan kebaikan tersebut adalah mampu memuaskan pelanggan.

Proses yang bermutu ini dimulai dengan pemahaman bahwa untuk melakukan sesuatu yang berkualitas tersebut tidak boleh dilakukan dengan santai, dan harus dengan sungguhsungguh. Seorang praktisi pendidikan,tidak boleh bekerja dengan seenaknya dan acuh tak acuh, sebab akan berarti merendahkan makna demi ridha Allah atau merendahkan Allah. ${ }^{15}$ Dalam surah Al-Kahfi disebutkan:

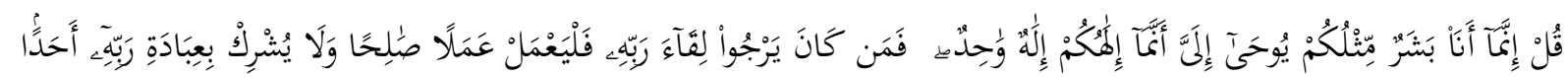

Artinya: Katakanlah: "Sesungguhnya aku ini manusia biasa seperti kamu, yang diwahyukan kepadaku: "Bahwa sesungguhnya Tuhan kamu itu adalah Tuhan yang Esa". Barangsiapa mengharap perjumpaan dengan Tuhannya, maka hendaklah ia mengerjakan amal yang saleh dan janganlah ia mempersekutukan seorangpun dalam beribadat kepada Tuhannya".(QS. Al-Kahfi:110)

Katakanlah hai Rasul kepada manusia: "Sesungguhnya aku ini tidak lain hanyalah manusia biasa seperti kamu semua, hanya saja aku ini diangkat oleh Allah sebagai utusan-Nya yang diberi wahyu yang menyatakan bahwa tidak ada Tuhan selain Dia. Dia-lah Tuhan Yang Maha Esa. Barangsiapa yang mengharap pahala dari Tuhan dan percaya terhadap adanya pertemuan dengan-Nya, maka hendaklah beramal saleh sebanyak-banyaknya dengan ikhlas semata-mata mengharap ridha-Nya, dan jangan sampai dalam beribadah itu tercampuri perbuatan syirik kepada selain Allah sekecil apapun!"

Maksud dari kata "mengerjakan amal shaleh" dalam ayat di atas adalah bekerja dengan baik (bermutu dan berkualitas), sedangkan kata "janganlah ia mempersekutukan seorangpun dalam beribadah kepada Tuhannya" berarti tidak mengalihkan tujuan pekerjaan selain kepada Tuhan (al-Haqq) yang menjadi sumber nilai intrinsik pekerjaan manusia. Dalam konteks, manajemen pendidikan Islam, hal tersebut berarti untuk mencapai mutu suatu lembaga pendidikan, maka harus fokus pada proses dan pelanggan. Dari pemahaman ayat tersebut, maka prosesnya adalah dalam hal melakukan amal shaleh, sedangkan pelanggannya adalah Allah. Allah diibaratkan menjadi pelanggan, karena Ia-lah yang menentukan apakah manusia ini baik (bermutu) atau tidak.

Seseorang harus mengerjakan sesuatu dengan sungguh-sungguh dan teliti (itqan), tidak separuh hati atau setengah-setengah, sehingga rapi, indah, tertib, dan bersesuaian antara satu dengan lainnya. Hal tersebut dijelaskan dalam surah al-Naml/27: 88:

\footnotetext{
${ }^{13}$ Kojin Mashudi, Telaah Tafsir..., 352.

${ }^{14}$ Ibid., 352

${ }^{15}$ Fathurrohman, Manajemen Mutu..., 198.

${ }^{16}$ Mashudi, Telaah Tafsir..., 12
} 


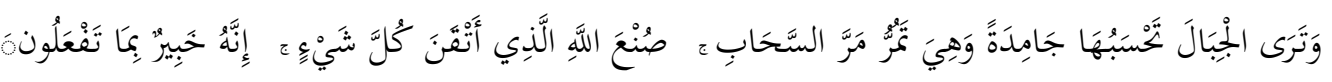

Artinya: Janganlah kamu sembah di samping (menyembah) Allah, Tuhan apapun yang lain. tidak ada Tuhan (yang berhak disembah) melainkan Dia. Tiap-tiap sesuatu pasti binasa, kecuali Allah. Bagi-Nyalah segala penentuan, dan hanya kepada-Nyalah kamu dikembalikan. ${ }^{17}$

Janganlah kamu menyembah atau memohon kepada Tuhan selain Allah, sesungguhnya tidak ada Tuhan selain Dia. Segala sesuatu selain Allah akan hancur dan lenyap, sedangkan Allah adalah Dzat yang abadi. Dia-lah yang mempunyai hukum dengan adil dan dengan keadilan-Nya Dia akan menghukumi hamba-Nya. Dan hanya kepadaNya semua makhluk di hari kiamat akan kembali untuk mendapatkan balasan dari amal perbuatannya.

Seseorang dituntut untuk memiliki dinamika yang tinggi, komitmen terhadap masa depan, memiliki kepekaan terhadap perkembangan masyarakat serta ilmu pengetahuan dan teknologi, dan bersikap istiqomah, seperti dijelaskan dalam ayat-ayat berikut ini:

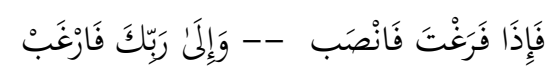

Artinya: Maka apabila kamu telah selesai (dari sesuatu urusan), kerjakanlah dengan sungguh-sungguh (urusan) yang lain, dan hanya kepada Tuhanmulah hendaknya kamu berharap. ${ }^{18}$

Proses yang bermutu dapat dilakukan jika anggota lembaga pendidikan bekerja secara optimal, mempunyai komitmen dan istiqamah dalam pekerjaannya. Tanpa adanya komitmen dan istiqomah dari para (pekerja), dalam konteks lembaga pendidikan, civitas akademika, maka lembaga pendidikan tersebut tidak mungkin dapat melakukan proses yang bermutu. Maka dari itu, untuk melakukan proses yang bermutu juga dibutuhkan personalia yang bermutu dan berdedikasi tinggi juga. Sehingga berbuat yang optimal atau berkualitas itu harus dilakukan dalam semua jenjang, semua lini dalam lembaga pendidikan. Apabila semua civitas akademika lembaga pendidikan mampu menyadari akan hal tersebut, maka mutu lembaga pendidikan tersebut akan dapat tercipta. ${ }^{19}$

Untuk dapat menghasilkan mutu yang baik dalam manajemen peningkatan mutu pendidikan, maka lembaga pendidikan Islam harus melakukan kontrol dan perencanaan yang bermutu. Ayat-ayat berikut ini dapat menjadi inspirasi bahwa kontrol dan perencanaan yang bermutu tersebut penting. Setiap orang dinilai hasil kerjanya, seperti dijelaskan dalam surah al-Najm/53: 39:

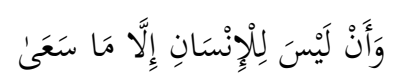

Artinya: dan bahwasanya seorang manusia tiada memperoleh selain apa yang telah diusahakannya. ${ }^{20}$

Masing-masing orang hanya menerima balasan dari apa yang telah dilakukannya sendiri, kalau baik akan memperoleh pahala dan apabila jelek akan mendapatkan siksa.Dengan melihat ayat di atas, maka setiap orang dalam bekerja dituntut untuk: 1) tidak memandang sepele bentukbentuk kerja yang dilakukan; 2) memberi makna kepada pekerjaannya itu;3) insaf bahwa kerja adalah mode of existence; 4) dari segi dampaknya, kerja itu bukanlah untuk Tuhan, namun untuk dirinya sendiri.

\footnotetext{
${ }^{17}$ Ibid., 357

${ }^{18}$ Ibid 515

${ }^{19}$ Fathurrohman, Manajemen Mutu..., 200.

${ }^{20}$ Mashudi, Telaah Tafsir..., 116
} 
Fungsi keuangan dalam banyak organisasi berperan sebagai supporting atau unit penunjang, oleh karena itu keuangan perlu di manage secara benar. Manajemen keuangan bisa diartikan suatu proses melakukan kegiatan mengatur keuangan dengan mengerakkan tenaga orang lain. ${ }^{21}$ Surah Al-Furqon ayat 67 :

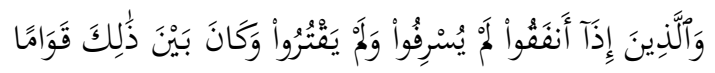

Artinya: Dan orang-orang yang apabila membelanjakan (harta), mereka tidak berlebihan, dan tidak (pula) kikir, dan adalah (pembelanjaan itu) di tengahtengah antara yang demikian. ${ }^{22}$

Orang-orang yang bertakwa tersebut dalam menginfakkan hartanya tidak berlebihan (boros) dan juga tidak kikir, akan tetapi mereka sederhana yakni berlaku sesuai dengan kemampuannya. Mereka tidak merasa bangga apabila dipuji karena memberi lebih banyak, atau juga merasa tidak malu atau sakit hati apabila dicaci karena memberi sedikit. Mereka tetap melandasinya dengan ikhlas sematamata mengharap ridha Allah.

Pentingnya mengelola aspek finansial dan non finansial secara efektif, efisien dan proporsional. Hal yang mendasar dalam nilai ajaran Islam adalah pengelolaan aspek finansial yang tidak berlebih-lebihan, artinya manajer harus melakukan perencanaan keuangan secara proporsional dan menghindari sikap israf (berlebih-lebihan) dan tabdzir (mubadzir) dalam penggunaannya. ${ }^{23}$

Organisasi perlu terlebih dahulu menentukan segmen pasar dan pelanggan yang menjadi target bagi organisasi atau badan usaha. Dalam perspektif pelanggan ini, Islam mengajarkan bahwa dalam memberikan pelayanan dari usaha yang dijalankan, baik itu berupa barang atau jasa jangan memberikan yang buruk atau tidak berkualitas, melainkan yang berkualitas kepada orang lain. Hal ini tampak dalam QS. Al-Baqarah ayat 267:

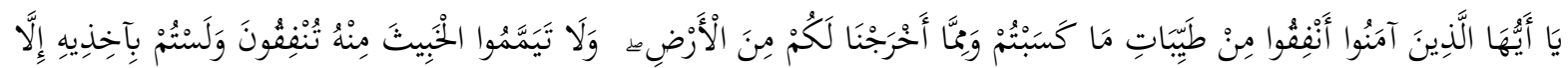

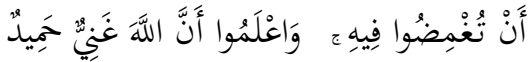

Artinya: Hai orang-orang yang beriman, nafkahkanlah (di jalan Allah) sebagian dari hasil usahamu yang baik-baik dan sebagian dari apa yang Kami keluarkan dari bumi untuk kamu. Dan janganlah kamu memilih yang buruk-buruk lalu kamu menafkahkan daripadanya, padahal kamu sendiri tidak mau mengambilnya melainkan dengan memincingkan mata terhadapnya. Dan ketahuilah, bahwa Allah Maha Kaya lagi Maha Terpuji. ${ }^{24}$

Ayat tersebut mengajarkan kepada kita tentang tata cara berinteraksi dengan orang lain, harus sesuai dengan etika yang berlaku agar tidak menimbulkan kesalah pahaman dan mampu memberikan yang terbaik bagi mereka. Dalam perspektif pelanggan, kebutuhan pelanggan diusahakan untuk dipuaskan dalam segala aspek, diantaranya harga, keamanan, dan ketepatan waktu. ${ }^{25}$ Kualitas pelayanan perlu menjadi substansi utama dalam sistem kepemimpinan organisasi, karena semakin tinggi nilai yang diberikan (pelayanan), maka semakin besar pula kepuasan pelanggan.

Berkenaan dengan kesediaan atau kemauan pegawai dalam memberikan pelayanan yang cepat dan tepat kepada konsumen. Kecepatan dan ketepatan pelayanan berkenaan dengan

${ }^{21}$ Maisyaroh, Manajemen Pendidikaan Analisis Substantif dan Aplikasinya dalam Institusi Pendidikan, (Malang: UNM, 2003), 97.

${ }^{22}$ Ibid., 233

${ }^{23}$ Zamroni, Manajemen Mutu..., 16.

${ }^{24}$ Mashudi, Telaah Tafsir..., 231

${ }^{25}$ Fandy Tjiptono \& Anastasia Diana, Total Quality Manajemen, (Yogyakarta: Andi, 2003), 14. 
profesionalitas. Dalam arti seorang pegawai yang profesional dirinya akan dapat memberikan pelayanan secara tepat dan cepat. Profesionalitas ini yang ditunjukkan melalui kemampuannya dalam memberikan pelayanan kepada konsumen. Dalam pelaksanaan suatu pekerjaan, seorang dikatakan profesional apabila dirinya bekerja sesuai dengan keahlian atau kemampuannya. Pekerjaan akan dapat dilakukan dan diselesaikan dengan baik secara cepat dan tepat apabila dilakukan oleh orang yang memiliki kemampuan sesuai dengan bidang pekerjaannya. Kepercayaan yang diberikan konsumen merupakan suatu amanat. Apabila amanat tersebut disia-siakan akan berdampak pada ketidakberhasilan dan kehancuran lembaga dalam memberikan pelayanan kepada konsumen. Untuk itu kepercayaan konsumen sebagai suatu amanat hendaknya tidak disia-siakan dengan memberikan pelayanan secara profesional melalui pegawai yang bekerja sesuai dengan bidangnya dan mengerjakan pekerjaannya secara cepat dan tepat, sesuai dengan firman Allah dalam QS. An-Nisa'ayat 58:

$$
\text { سَمِمِعًا بَصِيرًاً }
$$

Artinya: Sesungguhnya Allah menyuruh kamu menyampaikan amanat kepada yang berhak menerimanya, dan (menyuruh kamu) apabila menetapkan hukum di antara manusia supaya kamu menetapkan dengan adil. Sesungguhnya Allah memberi pengajaran yang sebaikbaiknya kepadamu. Sesungguhnya Allah Maha mendengar lagi Maha melihat. ${ }^{26}$

Berkenaan dengan pengetahuan atau wawasan, kesopanan, santun, kepercayaan diri dari pemberi layanan, serta respek terhadap konsumen. Apabila pemberi layanan menunjukkan sikap respek, sopan santun dan kelemahlembutan maka akan meningkatkan persepsi positif dan nilai bagi konsumen terhadap lembaga penyedia jasa. Assurance ini akan meningkatkan kepercayaan, rasa aman, bebas dari resiko atau bahaya, sehingga membuat konsumen merasakan kepuasan dan akan loyal terhadap lembaga penyedia layanan. Baik buruknya layanan yang diberikan akan menentukan keberhasilan lembaga atau organisasi pemberi jasa layanan. Dengan memberian pelayanan yang menunjukkan kesopanan dan kelemahlembutan akan menjadi jaminan rasa aman bagi konsumen dan yang berdampak pada kesuksesan lembaga penyedia layanan jasa. Berkenaan dengan hal ini, Allah SWT berfirman dalam QS. Ali Imran ayat 159:

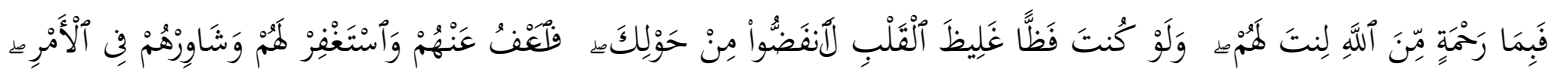

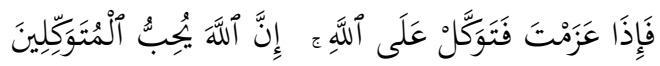

Artinya: Maka disebabkan rahmat dari Allah-lah kamu berlaku lemah lembut terhadap mereka. Sekiranya kamu bersikap keras lagi berhati kasar, tentulah mereka menjauhkan diri dari sekelilingmu. Karena itu maafkanlah mereka, mohonkanlah ampun bagi mereka, dan bermusyawaratlah dengan mereka dalam urusan itu. Kemudian apabila kamu telah membulatkan tekad, maka bertawakkallah kepada Allah. Sesungguhnya Allah menyukai orang-orang yang bertawakkal kepadaNya. ${ }^{27}$

\section{Isyarat Mutu Dalam Al-Hadits}

Hadits diriwayatkan Imam Bukhari di kitab Sahih Bukhari No. 3955, didalamnya dapat diambil kesimpulan bahwa dalam segala hal umur tidak bisa dijadikan patokan atau ukuran bahwa keilmuannya mumpuni:

\footnotetext{
${ }^{26}$ Mashudi, Telaah Tafsir..., 464

${ }^{27}$ Ibid., 371
} 


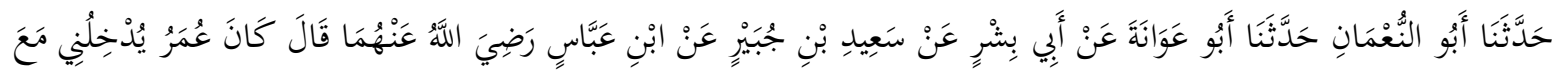

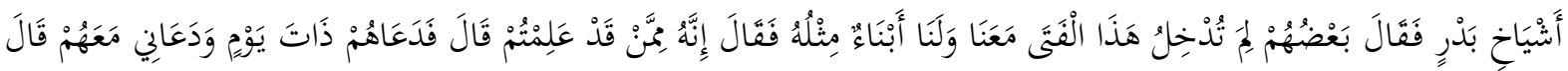

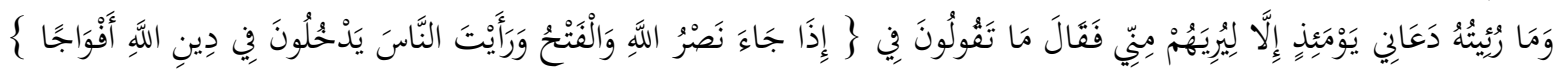

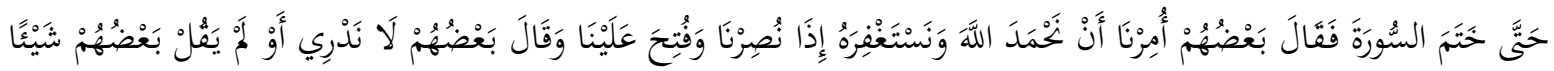

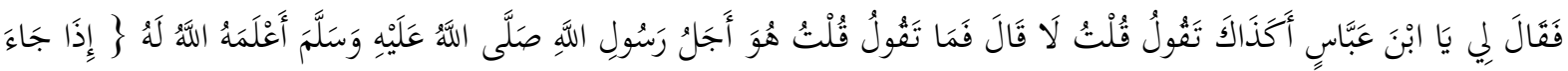

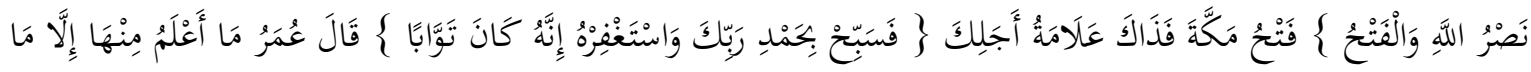

Artinya: Telah menceritakan kepada kami Abu Nu'man Telah menceritakan kepada kami Abu 'Awanah dari Abu Bisyr dari Said bin Jubair dari Ibnu Abbas radhiallahu'anhuma, Umar Pernah mengajakku dalam sebuah majelis orang dewasa, sehingga sebagian sahabat bertanya "Mengapa si anak kecil ini kau ikut sertakan, kami juga punya anak-anak kecil seperti dia?" Umar menjawab, "Kalian maklum, anak ini punya "Kualitas" tersendiri." Kata Ibnu Umar, maka suatu hari Umar mengundang mereka dan mengajakku bersama mereka. Seingatku, Umar tidak mengajakku saat itu selain untuk mempertontonkan kepada mereka kualitas keilmuanku. Lantas Umar bertanyal, "Bagaimana komentar kalian tentang ayat "Seandainya pertolongan Allah dan kemenangan datang (1) dan kau lihat manusia masuk agama Allah dengan berbondong-bondong (2) -hingga ahkir surat (QS. Alfath 1-3). Sebagian sahabat berkomentar, "Tentang ayat ini, setahu kami, kita diperintahkan agar memuji Allah dan meminta ampunan kepada-Nya, tepatnya ketika kita diberi pertolongan dan diberi kemenangan." Sebagian lagi berkomentar, "Kalau kami tidak tahu." Atau bahkan tidak berkomentar sama sekali. Lantas Umar bertanya kepadaku, "Wahai Ibnu Abbas, beginikah kamu berkomentar mengenai ayat tadi? "TIDAK" Jawabku."Lalu komentarmu? Tanya Umar. Ibnu Abbas menjawab, "Surat tersebut adalah pertanda wafat Rasulullah sudah dekat, Allah memberitahunya dengan ayatnya, "Jika telah datang pertolongan Allah dan kemenangan', itu berarti penaklukan Makkah dan itulah tanda ajalmu (Muhammad), karenanya "Bertasbihlah dengan memuji Tuhanmu dan mohonlah ampunan, sesungguhnya Dia Maha Menerima tobat. Kata Umar, "Aku tidak tahu penafsiran ayat tersebut selain seperti yang kamu (Ibnu Abbas) ketahui." ${ }^{18}$

Hadits diriwayatkan Imam Bukhari di kitab Sahih Bukhari No. 3304, dapat kita ambil kesimpulannya bahwa tidak perlu melakukan pekerjaan yang bermacam2 akan tetapi fokus dan mengerjakaan satu pekerjaan dengan baik maka hasilnya akan berkualitas.

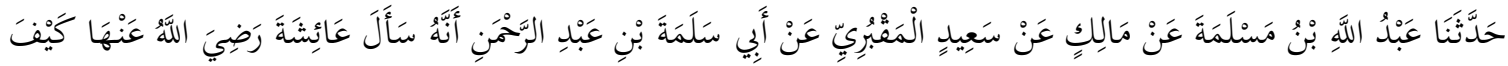

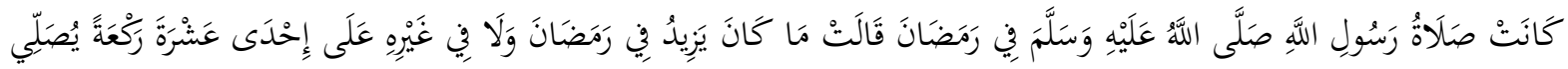

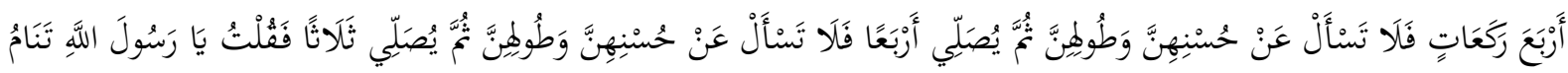

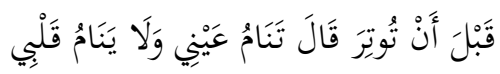

Artinya: Telah bercerita kepada kami Abdullah bin Maslamah dari Malik dari Sa'id Al Maqburiy dari Abu Salamah bin 'Abdur Rahman bahwa dia bertanya kepada 'Aisyah

${ }^{28}$ Abu Abdullah Muhammad bin Ismail Al-Bukhari, Ensiklopedia Hadits; Shahih al-Bukhari, Terjemah Masyhar dan Muhammad Suhadi, (Jakarta: Almahira, 2011) 
radhiallahu'anhu; "Bagaimana tata cara shalat Nabi pada bulan Ramadan?".. 'Aisyah radhiallahu'anhu menjawab, "Beliau shalat (sunnah qiyamul lail) pada bulan Ramadan dan bulan-bulan lainnya tidak lebih dari sebelas rakaat. Beliau shalat empat rakaat, maka jangan kamu tanya tentang kualitas bagus dan panjangnya, kemudian beliau shalat lagi empat rakaat, maka jangan kamu tanya tentang kualitas bagus dan panjangnya kemudian beliau shalat tiga rakaat. Aku pernah bertanya, "Wahai Rasulullah, apakah baginda tidur sebelum melaksakan shalat Witir? '. Beliau menjawab, "Mataku memang tidur tapi hatiku tidaklah tidur". ${ }^{29}$

Hadits yang diriwayatkan Imam Abu Daud di kitab Sunan Abu Daud No. 577, dapat ditarik kesimpulan bahwa dalam suatu organisai pasti ada klaster, tidak mungkin orang berpendidikan rendah dijadikan pimpinan, pasti dalam susunan organisasi diatur kebutuhan dan kesesuaian pendidikan dan mutunya.

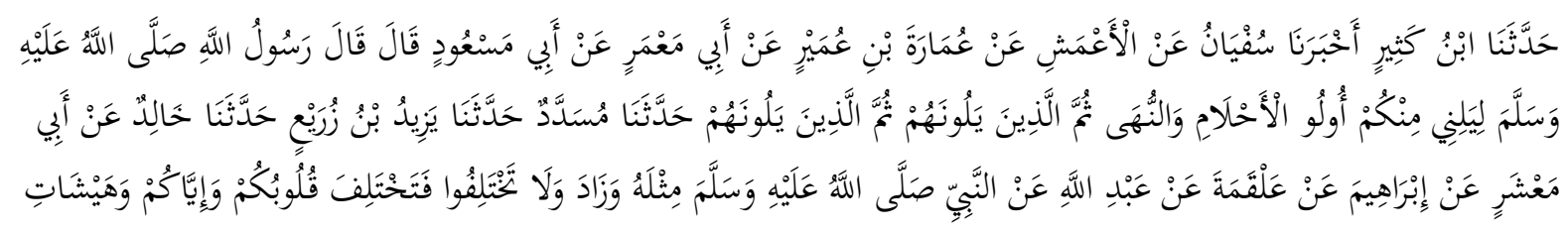

Artinya: Telah menceritakan kepada kami Ibnu Katsir telah mengabarkan kepada kami Sufyan dari Al-A'masy dari 'Umarah bin 'Umair dari Abu Ma'mar dari Abu Mas'ud dia berkata; Rasulullah bersabda, "Hendaklah yang menempati shaf di belakangku adalah orang-orang dewasa dan cerdik pandai, kemudian orang-orang yang (kualitas dan umurnya) setelah mereka, kemudian orang-orang yang (kualitas dan umurnya) setelah mereka." Telah menceritakan kepada kami Musaddad telah menceritakan kepada kami Yazid bin Zurai' telah menceritakan kepada kami Khalid dari Abu Ma'syar dari Ibrahim dari Alqamah dari Abdullah dari Nabi semisal dengannya, dan menambahkan lafazh; Dan janganlah kalian berselisih sehingga menyebabkan hati kalian saling berselisih. Dan jauhilah olehmu suara ribut seperti di tengah pasar. ${ }^{30}$

\section{Manajemen Mutu Dalam prespektif Pendidikan Islam}

Manajemen mutu dalam pendidikan merupakan cara dalam mengatur semua sumber daya pendidikan, yang diarahkan agar semua orang yang terlibat di dalamnya melaksanakan tugas dengan penuh semangat dan berpartisipasi dalam perbaikan pelaksanaan pekerjaan sehingga menghasilkan output yang sesuai bahkan melebihi harapan "pelanggan pendidikan". ${ }^{11}$ Karena pada dasarnya yang diharapkan oleh masyarakat dari adanya lembaga pendidikan adalah bagaimana masyarakat dapat mengambil manfaat dari berdirinya lembaga pendidikan, khususnya lembaga pendidikan Islam.

Pendidikan yang berkualitas adalah pendidikan yang melahirkan output-output yang berkualitas pula. Realitaya, pendidikan yang ditangani oleh lembaga pendidikan utamanya lembaga pendidikan Islam saat ini masih jauh dari kata sempurna atau kurang berhasil melahirkan output-output yang berkualitas pula.

Problem yang dihadapai pendidikan Islam adalah sebagai berikut: 1) Para manajer pendidikan Islam tidak sungguh-sungguh dalam mengelola lembaga pendidikannya, 2) Para pendidik pendidikan Islam tidak lagi berusaha memeperbarui strategi pembelajaran, 3)

\footnotetext{
${ }^{29}$ Ibid.,

${ }^{30}$ Abu Dawud, Sunan Abu Dawud, (Beirut: Maktabah al-'Isriyah, t.t)

${ }^{31}$ Winarsih, S., Kebijakan Dan Implementasi Manajemen Pendidikan Tinggi Dalam Meningkatkan Mutu Pendidikan, (Bandung: Cendekia, 2017), 51.
} 
Masyarakat muslim yang lebih melihat kepada penampilan gedung daripada kualitas sebagai subtansi pendidikan Islam. ${ }^{32}$

Setiap lembaga pasti punya caranya sendiri-sendiri untuk menjamin mutu pendidikan yang mereka jual kepada masyarakat. Setiap lembaga pendidikan akan bersaing untuk menjadikan lembaga pendidikan mereka dapat dikatakan baik oleh masyarakat. Acuan mutu yang digunakan untuk mencapai dan memenuhi mutu pendidikan pada satuan pendidikan adalah Standar Nasional Pendidikan (SNP),8 dan standar-standar lain yang disepakati oleh kelompok masyarakat. Standar nasional pendidikan adalah standar yang dibuat oleh pemerintah, sedangkan standar lain adalah standar yang dibuat oleh satuan pendidikan dan/atau lembaga lain yang dijadikan acuan oleh satuan pendidikan untuk meningkatkan mutunya. Standar-standar lain yang disepakati oleh kelompok masyarakat digunakan setelah SNP dipenuhi oleh satuan pendidikan sesuai dengan kekhasan jalur, jenjang, dan jenis pendidikan.

Pendidikan memiliki posisi yang penting dalam kehidupan manusia, karena tanpa pendidikan manusia tidak akan mengalami suatu peradaban. Oleh karenanya, dengan adanya pengelolaan mutu pada sebuah lembaga pendidikan akan sangat membantu bagi terlaksananya suatu peradaban yang menjunjung tinggi perubahan untuk maju sesuai dengan perkembangan zaman. Mengingat pentingnya pendidikan bagi kehidupan manusia, maka Islam sebagai agama yang rahmatan lil alamin, memberikan perhatian serius terhadap perkembangan pendidikan dan bagi kelangsungan hidup manusia. Lembaga pendidikan Islam akan terus berkontribusi dalam membangun bangsa tidak hanya dengan melahirkan outputputput yang berintelektual tinggi atau output yang memiliki kualitas tinggi.

Pendidikan Islam juga difokuskan untuk menghasilkan kemampuan yang handal melalui pemberdayaan sumber daya manusia secara maksimal sehingga melahirkan manusia yang terpelajar dan berbudaya yang dapat mengangkat harkat dan martabatnya dalam pergulatan dunia internasional yang semakin kompetitif. ${ }^{33}$ Untuk menjadikan output yang memiliki kulaitas yang baik dari sebuah lembaga pendidikan maka perlu adanya sebuah perbaikan dan pembaruan dari lembaga pendidikan Islam yang sesuai dengan kebutuhan masyarakat dan perkembangan zaman.

\section{KESIMPULAN}

Kriteria umum yang telah disepakati bahwa sesuatu itu dikatakan bermutu, pasti ketika sesuatu itu bernilai baik atau mengandung makna yang baik. Sebaliknya sesuatu itu dikatakan tidak bermutu, bila sesuatu itu mempunyai nilai yang kurang baik, atau mengandung makna yang kurang baik. Dalam konteks pendidikan, apabila seseorang mengatakan sekolah itu bermutu, maka bisa dimaknai bahwa lulusannya baik, gurunya baik, gedungnya baik, dan sebagainya. Untuk menandai sesuatu itu bermutu atau tidak seseorang memberikan simbolsimbol dengan sebutan-sebutan tertentu, misalnya sekolah unggulan, sekolah teladan, sekolah percontohan dan lain sebagainya.

Mutu merupakan realisasi dari ajaran ihsan, yakni berbuat baik kepada semua pihak disebabkan karena Allah telah berbuat baik kepada manusia dengan aneka nikmat-Nya, dan dilarang berbuat kerusakan dalam bentuk apapun. Ihsan berasal dari kata husn, yang artinya menunjuk pada kualitas sesuatu yang baik dan indah. Dictionary menyatakan bahwa kata husn, dalam pengertian yang umum, bermakna setiap kualitas yang positif (kebajikan, kejujuran, indah, ramah, menyenangkan, selaras, dll). Dalam terminologi ilmu tasawuf, ihsan berarti seseorang menyembah Allah seolah-olah ia melihatNya, dan jika ia tidak mampu membayangkan malihatNya, maka orang tersebut mambayangkan bahwa sesungguhnya Allah melihat perbuatannya.Terdapat 3 hadits yang dikutip dari kitab sahih bukhari dan sahih abu daud, bawasannya untuk melihat seseorang berkualitas tidak bisa dipandang dari segi umur

\footnotetext{
${ }^{32}$ Mujamil Qomar, Menggagas Pendidikan Islam, (Bandung: PT Remaja Rosdakarya, 2014), 135.

${ }^{33}$ Ibid., 130.
} 
maupun seberapa banyak pekerjaan yang dilakukan, namun dapat dilihat dari tingkat keilmuan dan hasil yang sudah didapatkan.

Pendidikan Islam juga difokuskan untuk menghasilkan kemampuan yang handal melalui pemberdayaan sumber daya manusia secara maksimal sehingga melahirkan manusia yang terpelajar dan berbudaya yang dapat mengangkat harkat dan martabatnya dalam pergulatan dunia internasional yang semakin kompetitif.

\section{Daftar Pustaka}

Al-Bukhari, Abu Abdullah Muhammad bin Ismail, Ensiklopedia Hadits; Shahih al-Bukhari Terjemah Masyhar dan Muhammad Suhadi. Jakarta: Almahira. 2011

Baharun, Hasan dan Zamroni. Manajemen Mutu Pendidikan Ikhtiar dalam Meningkatkan Mutu Pendidikan Madrasah melalui Pendekatan Balanced Scorecard. Tulungagung: Akademia Pustaka. 2017.

Dawud, Abu. Sunan Abu Dawud. Beirut: Maktabah al-'Is\}riyah. t.t.

Fathurrohman,Muhammad. Manajemen Mutu Pendidikan Islam Dalam Perspektif Alqur'an Dan Hadits. AL-WIJDÁN Journal of Islamic Education Studies. Volume III, Nomor 2, November 2018.

Hadis, Abdul dan Nurhayati. Manajemen Mutu Pendidikan. Bandung: Alfabeta. 2010.

Hasan, M. Ali dan Mukti Ali. Kapita Selekta Pendidikan Islam. Jakarta: Pedoman Ilmu Jaya. 2003.

Komariyah, Aan dan Cepi Triatna. Visonary Leadership Menuju Sekolah Efektif. Jakarta: P. T. Bumi Aksara. 2008.

Maisyaroh. Manajemen Pendidikaan Analisis Substantif dan Aplikasinya dalam Institusi Pendidikan. Malang: UNM. 2003.

Mashudi, Kojin. Telaah Tafsir Al-Muyassar. Malang: Intelejensi Manusia. 2018.

Masyitoh, M. H. "Manajemen Mutu Pendidikan Perspektif QS. Ar-Ra'du Ayat 11 Dan Impelemtasinya Dalam Pengelolaan Madrasah" dalam JUMPA Jurnal Manajemen Pendidikan, Vol.1, No. 1. Februari - Oktober 2020.

Murata, Sachiko dan William C.Chittick. Trilogi Islam: Islam, Iman, dan Ihsan, terjemah :Ghufron A. Jakarta: Raja Grafindo Persada. 1997.

Qomar, Mujamil. Menggagas Pendidikan Islam. Bandung: PT Remaja Rosdakarya. 2014.

Tjiptono, Fandy \& Anastasia Diana. Total Quality Manajemen. Yogyakarta: Andi. 2003.

Winarsih, S., Kebijakan Dan Implementasi Manajemen Pendidikan Tinggi Dalam Meningkatkan Mutu Pendidikan. Bandung: Cendekia, 2017. 
Zahroh, Aminatul dan Binti Maunah. TOTAL QUALITY MANAGEMENT (TQM): Sebuah Langkah dalam Mengedepankan Kualitas Output melalui Sistem Kontrol Mutu (Quality Control) Sekolah. Jurnal Realita. Vol. 13 No. 2 Juli 2015. 